Rev. Andrzej Proniewski

Uniwersytet w Bialymstoku

iD $0000-0003-0382-3646$

DOI: $10.15290 /$ std.2019.05.10

\title{
REFORM OF THE CATHOLIC CHURCH
}

The reform of the Church initiated by the Second Vatican Council cannot be equivalent to the change in society dictated by the intellectual development or civilizational progress. The article focuses on the foundation of an authentic reform that touches upon the faith of Christians that, requires continuous deepening and purification and leads to freedom. Subsequently, this freedom with the guidance of the Holy Spirit prompts the faithful to service and forgiveness. The main motive of the Church's ongoing reform is the salvation of her believers. Therefore, the reform will reach its goals when a great number of the Church's members, according to God's plan, will achieve perfect communion with God.

Key words: reform, Church, Congar, Ratzinger, salvation.

\section{Introduction}

On September 1, 1990, during the Communion and Liberation Movement's annual meeting in Rimini, Italy, the then Prefect of the Congregation for the Doctrine of the Faith, Cardinal Joseph Ratzinger gave an address entitled An Ever-Reforming Community. ${ }^{1}$ The thoughts of the future Pope Benedict XVI that are contained in this lecture are still relevant today and clearly get to the

Part of this address was included in a collection of Joseph Ratzinger's articles published in Rome in 2006 after his election as pope. See J. Ratzinger, Kościót. Wspólnota w drodze, Kielce 2009, pgs. 121-145. The subject of this address was on what the Second Vatican Council intuited and itself a community of continuous renewal and reform. This topic has been discussed extensively in theological literature, including, in particular, the collected work edited by T. Gałuszka, T. Graff, G. Ryś: Ecclesia semper reformanda. Kryzysy i reformy średniowiecznego Kościoła, Cracow 2013 as well as the book by Gian Franco Svidercoschi entitled Sobór który trwa, Cracow 2003. 
heart of the matter, which is the pressure placed on the Church by proponents of the conservative option, on the one hand, and those who want to reform the Church by making it appear modern, on the other. How can one reconcile both camps? According to which criteria should the reality of the situation in which the community of those who believe in Jesus Christ be assessed? And finally, what changes are necessary, and should this Church reform really be understood like any other reform?

\section{Reform in Light of the Documents of the Second Vatican Council}

The Pastoral Constitution on the Church in the Modern World: Gaudium et Spes (GES) points out the transformations have occurred in man's surroundings and influenced the way in which he achieves his aims. Man has witnessed how the main spheres of his life: social, moral, psychological, and religious conditions have undergone a metamorphosis. As the Conciliar Fathers point out, the rapidity with which these transformations have taken place have caused man to become unbalanced because he is unable to find himself within this new situation. As a result, it seems extremely difficult for man to reconcile his human questions and doubts as well as his desires and expectations. Within this "existential shock," it is necessary to return to the source of all human questions: "[W] hat is man? What is the sense of sorrow, of evil, of death, which continues to exist even despite so much progress? What purpose have these victories purchased at so high a cost? What can man offer to society, what can he expect from it? What follows this earthly life?" (GES, 10). "Emancipated" theories that are not based on virtue are not able to provide responses to these questions. For, often the only carrying capacity of such theories is the catchword "novel," which attracted so many at the cost of rejecting that which is essential. This is where the Gospel has its unique role to play: "The Church also maintains that beneath all changes there are many realities which do not change and which have their ultimate foundation in Christ, Who is the same yesterday and today, yes and forever. Hence under the light of Christ, the image of the unseen God, the firstborn of every creature, the council wishes to speak to all men in order to shed light on the mystery of man and to cooperate in finding the solution to the outstanding problems of our time."

This seems to be the hotspot within the debate on Church reform, since She is the one who has been entrusted with the truth about God in Whom

Ibidem. 
an explanation for the meaning and purpose of man's existence is always found. It is not necessary to focus too much on what happens when this interdependence is severed for the sake of pronouncing the modernization of the Church today or adapting the teachings of the Church to the spirit of the current times. The objections of many contemporary critics of the Church are contained in expressions such as: "fossilized, ossified structures, outdated language and messages, and ancient traditions..." Gaudium et Spes points out that the Church was never an enemy of progress; rather, She has always understood progress differently and, unlike society, studies its long-term effects: "The experience of past ages, the progress of the sciences, and the treasures hidden in the various forms of human culture, by all of which the nature of man himself is more clearly revealed and new roads to truth are opened, these profit the Church too" (GES, 44). The Church has always been capable of being resilient and flexible due to the timelessness of the Gospel, the language of which can always be reconciled with the context of a given culture or society.

\section{What is the Aim of Authentic Reform?}

Joseph Raztinger's thought initially seems to point to human freedom, the value of which has always aroused particularly strong reactions among those who have tried to limit it in different ways. The issue of the freedom that the Church seeks to cultivate seems to be a particularly heavy burden to man because it touches upon the interior path to happiness. One cannot remain indifferent to the principles set forth by Christ. The Church cannot be based on the principles of democracy because She is naturally made up of a majority and a minority that, in fact, is at times rather considerable. A community that must be based solely on the opinion of the majority would be a purely human creation. In such a community, opinion would eradicate faith. And, it is here that a strong conflict in the very understanding of faith arises. As Joseph Ratzinger points out, faith in its proper sense is the individual statement: "It seems to me," or the communal statement: "It seems to us." If we, as Christ's followers, remained only on this level, then we would be expressing only ourselves. This would be a dangerous tendency because today every person wants to promote himself, and many individuals want to emphasize their uniqueness.

An interesting approach that the Prefect for the Congregation of the Doctrine of the Faith uses is to contrast two types of Christians: activists and admirers. The former rely on their mind and their experience. The only realm in which they exist is the world of things and unceasing activity. Their opponents, on the other hand, keep in mind the value of the mystery of faith 
because they consider the tangible world too narrow and unable to exhaust all doubt. Using a beautiful metaphor, the former pope compares Church reform to the work of an artist who is able to envision the final form of his work through the eyes of his imagination and who gradually removes that which is unnecessary. This is how Michelangelo perceived his own work. He essentially extracted beauty and freed it from being imprisoned within a formless mass of stone. Purification (ablatio) leads to community (congregatio). ${ }^{3}$ The most essential initiative that purifies the Church is the continual renewal of the act of faith, which makes it possible to reach that which is limitless. Cardinal Ratzinger bitterly calls to mind the effects of positivism, which has found its way into the consciousness of many people, simultaneously eradicating the sacrum from their lives and the dimension of the limits that are essential to existence, which man sets only at the prospect of his abilities. Excluding God as a being greatly reduces man and his desire for freedom to matter and its finiteness. The following is an important sentence in the then Cardinal Ratzinger's lecture: "Faith itself, in all its greatness and plentitude, is, therefore, the constant reform of the Church that we need." ${ }^{4} \mathrm{He}$ builds his conviction that the activity of the faithful should not be associated with ecclesial institutions at all cost around this thought. In other words, not every form of involvement within the life of the Church requires that a person belong to a specific committee, organization, foundation, or movement. The Cardinal continues by sharing this deep thought about faith: "We need not a more human but a more divine Church because only then can [the Church] be truly human. For this reason, everything that is of human creation within the Church should be of service and subservient to what has greater value and is the most important." An attitude of service that seeks to put oneself second and that interiorly penetrates the Church is an important aspect of Church reform. This attitude must open individuals to the Holy Spirit, Who is the giver of freedom; otherwise, an attitude of service will develop into a kind of slavery that creates a sense of suffocation and constraint within the community. The demand for "less structure and more Spirit of freedom" is not a manifestation of the liberalization of Christianity. Rather, it is an expression of opposition to political and economic structures that entangle the increasingly broader circles of society in a trap of dependence. After discussing faith and freedom

3 See J. Szymik, Kościót w sercu Boga. Wybrane watkiJ. Ratzingera/Benedykta XVI eklezjologii communio, „Studia Gniesniensia” 2013, 27, pgs. 73-75.

4 Por. J. Ratzinger, Kościót..., pg. 134.

5 See ibid. pg. 135. 
from structures, Ratzinger emphasizes the role of forgiveness as a personal experience of faith.

Starting from the act of creation, Joseph Ratzinger presents man as a noble being who possesses a form that is contaminated by sin. From this moment onward, man needs the unceasing help of a [Divine] Sculptor Who alone holds the chisel that can restore man's original beauty. Actions that avoid, reduce, or completely eliminate a sense of guilt and sin wreak great havoc in the hearts of men. ${ }^{6}$ Since morality in itself without any reference to God becomes an unbearable burden, Ratzinger demonstrates how faith-morality-forgiveness-reparation must be inextricably linked in man's experience. ${ }^{7}$ In concluding, the future Pope Benedict XVI points to the saints' presence within the Church as if to say: the saints-what their lives looked like, how many of them were martyred, how their teachings arose, and what kinds of teachings they left behind-all tell us about the times in which they lived... According to Ratzinger, the saints' behavior is a constant example of reform in the Church-they always point to the superiority of divine matters over human affairs and, in so doing, are the proper majority within the community of the Church. The example of the saints makes the Church more dynamic and supports Her members who are still on their pilgrimage to their final destination. ${ }^{8}$

\section{Yves Cognar's Thought}

Before Benedict XVI developed his theological ideas on ecclesiology, Catholic thought had been greatly enriched by the work of another great theologian of the $20^{\text {th }}$ century: the French Dominican Yves Congar. Congar was the main expert at the Second Vatican Council and introduced many valuable changes that have been taking place up to today in order to renew the face of the Church. The almost half-century of writing and research of

6 In this regard, critics of Freud's psychoanalysis point out that it has a destructive effect on some of the natural intuitions that God has instilled in man. Most radically, the Austrian psychoanalyst was given a higher status than Jesus because he not only forgave sin, but also numbed man's sense of guilt and sin.

7 Ratzinger takes this construction from the Pentateuch because it conveys a proper and comprehensive understanding of forgiveness, which must always be grounded within the context of norms and obligations.

8 By referring to examples from history, Benedict XVI points out how the grassroots renewal that the saints carried out was cyclical in nature. These initiatives represented the part of the Church that did not express the voice majority, occupied the margins of society, and was small in number. The creative power of the people of the Church is evident in numerous moral and spiritual renewal initiatives that took place in Europe. See A. Nicholas, Myśl Benedykta XVI. Wprowadzenie do myśli teologicznej Josepha Ratzingera, Kraków 2006, pg. 265. 
this French religious has inspired many of those who study Church history as well as theologians who are responsible for the Church's activity in the modern world. Joseph Ratzinger based his concept of Church reform largely on the observations of his predecessor Cognar, who published the following book that contains significant elements of his teaching after the Second World War: True and False Reform in the Church. ${ }^{9}$

The key to Cognar's concept of Church reform is to make a clear distinction between that which can change within the community of the faithful and that which cannot be reformed. Such a division is necessary because of the divine and human nature of the Church. The constitutive element that determines the Church's identity is what we call the deposit of the faith, which is generally comprised of Sacred Scripture and Tradition. Strictly speaking, however, it is everything that the Church has received from Christ as the fruit of his Passion and Resurrection. The core of our faith can only be received, lived out, and passed on. These three actions can be understood as one continuous activity because whenever one of these elements is lacking, the process of faith is incomplete. Without the part of the Church that does not change, the Church would lose its purpose, which is man's salvation, over the centuries. Because of the truth about Christ that the Church has safeguarded, She continues to be an effective and real instrument of salvation and the place where one can encounter God. According to Congar, the structure of the Church cannot change. This does not mean, however, that a radical discussion about reforming Her is out of the question. The reason for this is that the Church is not just Her structure. The supernatural ability of the Church's structures is to be embodied within the community. In this way, only the form, manner, surroundings, and circumstances change, but not the content. These structures are embodied by people, who are an indispensible-albeit unreliable and imprecise in their interpretation and implication of these structures-element. The structure must continuously discover actual channels through which it can-by means of its power-reach the heart and mind of every person. This is the main reason why continual Church reform-a reform understood as the desire for Christ in the Church to remain alive in the deposit of the faith, the liturgy, and sacramental and apostolic service-is necessary. As a gift of God and the seed of supernatural life, the structure of the Church is perfect and it must be embodied through a "reformability" of life. According to Fr. Congar, loosely balancing these two objects without clearly differentiating between them has led to the majority of most ecclesiological heresies. The dissonance can be observed in countless conversations and opinions wherein individuals

Y. Congar, Prawdziwa i fatszywa reforma w Kościele [True and False Reform in the Church], Kraków 2001. 
seek to apply historical criteria to the Church's immutability. Theology thought is confronted with an increasingly heated conflict in this difficult role of penetrating the world of perfect structures with the help of human reason. Congar addresses this salvific sphere in order to more fruitfully translate this ideal to the level of human dilemmas and understatements. This approach is vital because, without it, it is difficult to function on an earthly plane. It is also necessary to examine the earthly sphere, meaning history and the human dimension; however, according to Congar, this endeavor is less objective than contemplating pure structure. That which the Church experiences from within as a result of the divine structures that penetrate our life is a precious treasure for two reasons. First, the world asks the Church questions about Her identity and seeks answers to the questions that bother it. Man cannot find the ultimate answers to these questions within himself; therefore, he looks more and more hopefully to Christ in His Church. The second important argument is the fact that, in its experience of itself, the world gives the Church healthy and authentic mechanisms for change. Congar defines this as the process of returning to the Church through the world not only that which one has received from Her in embryonic form, but even more. For, the world can prophecy to the Church. In what way? Severe criticisms of the negative attitudes, deviations, and abuses within the Church can be interpreted as Christ's call to conversion.

When reading Cognar's works, four main themes that serve as the basis of his single effective reform of the Church are evident. ${ }^{10}$ The first theme is the need for reform through love. People, who the Church loves and understands, are called to change. This change must arise primarily from the involvement of living elements of the community rather than through institutional changes. It is impossible to renew the face of the Church and to strengthen Her by creating new councils, parishes, offices, or means of control without calling actual people to unity, conversion, reflection, and a change of life. Reform must be expressed through the language of a faith, hope, and love inspired by the Holy Spirit; otherwise, it will collapse under the weight of criticism and human unreliability. A love that induces change must be manifested in drawing near, accompaniment, and cooperation at times in a painful experience. It is not enough to say that one must love; for, one must love wisely. The world has been wounded deeply by the distortion of freedom, truth, tolerance, and mercy.

If the Church is to love wisely, then She must embrace Her universality, which protects Her from fulfilling the wishes of a small group of Her members. Congar understands communion as catholicity. The temptation of a reformer

10 See G. Strzelczyk, O reformowalności Kościoła i pożytku z czytania starych ksiażek, in: W drodze, 1997, 10 (290), pgs. 21-24. 
is to promote his cause and way of thinking to such a degree that he suddenly finds himself outside of the Church. Only by pursuing the Truth, which involves accepting a different order of emphases and various approaches to It, does one maintain unity. The mystery of the Church is that She possesses the entire Truth only as a whole. This also means, however, that an individual reaches a considerably higher level of knowledge of the Truth when he remains in communion with the Church than when he discovers Truth privately.

The next element of correct reform is patience, or the ability to await. A hallmark of ideas within the Church is that they must develop and mature gradually over time because sudden changes, revolution, and activity that occur before the necessary period of observation, discernment, and acquired readiness harm the Church. The Church makes room for the proper amount of time to allow for what is valuable to appear and become stronger. Before all, time purifies the Church of a sense of urgency, bad spontaneity, and transience. That which serves the community must reflect the eternal to some degree-it must serve man for longer and more deeply than immediately, even should it be for a short time.

A final and extraordinarily important pillar of change within the Church must be a continual renewal of Tradition with a capital " $T$ " that is both animated and lived out. This Tradition is something other than simply habit, with which it is easily confused and used interchangeably. Manny people, after all, live according to customs that only bear the traits of tradition or are distantly derived from it. The living Tradition of the Church must be continually rediscovered because it has developed out of the community's experience just like, for example, the truth of the faith has matured to its present form, the Church led by the Holy Spirit has discovered new aspects of the truth and, in so doing, has become stronger and sanctified.

Moreover, Yves Cognar's thought touches on a certain phenomenon that occurs when reforms in the Church are introduced-namely, throughout history the many saints, who began these reforms came forth from the peripheries of both the world and the Church. These saints existed at the intersection of these two realities, and they lived and taught among people who were unable to find their place in either. Reform that arose out of these tangential realities radiates to both the world and the Church. Therefore, it is possible to risk stating that, throughout the history of the Church, a special group of saints with a particular charism to renew and inspire many people took on the work of reform, and they did so without having social positions that facilitated their work and the promotion of their ideas. 


\section{Conclusion}

The Church reform that two eminent contemporary theologians-Yves Congar and Benedict XVI-propose involves rebuilding the Church from within. It is possible to create a community of believers that is capable of continuous reform and renewal by using the means that God has given us. In this way, such activity will not be an outwardly symbolic change, but rather a real rejuvenation that will make the Pilgrim People of God able to courageously confront the challenges of our time and triumphantly pass through the trials that will come.

The People of God who constitute the Church cannot believe exclusively in their own potential; rather, they must entrust their path to God, Who is the immutable answer to every human question.

Słowa kluczowe: reforma, Kościół, Congar, Ratzinger, zbawienie.

\section{Bibliografia:}

1. Congar Y., Prawdziwa i fatszywa reforma w Kościele [True and False Reform in the Church], Kraków 2001.

2. Gałuszka T., Graff T., Ryś G., Ecclesia semper reformanda. Kryzysy i reformy średniowiecznego Kościoła, Kraków 2013

3. Nicholas A., Myśl Benedykta XVI. Wprowadzenie do myśli teologicznej Josepha Ratzingera, Kraków 2006.

4. Ratzinger J., Kościót. Wspólnota w drodze, Kielce 2009.

5. Strzelczyk G., O reformowalności Kościoła i pożytku z czytania starych ksiażek, „W drodze” 1997, 10 (290).

6. Svidercoschi G. F., Sobór który trwa, Kraków 2003.

7. Szymik J., Kościót w sercu Boga. Wybrane watki J. Ratzingera/Benedykta XVI eklezjologii communio, „Studia Gniesniensia” 2013, 27. 